\title{
Effect of nitrogen scheduling on nitrogen use efficiency and performance of wheat (Triticum aestivum L.) in light textured soil
}

\author{
U.P. SHAHI, MANOJ KUMAR, B. P. DHYANI, ASHOK KUMAR AND YOGESH KUMAR
}

Received : 16.01.2016; Revised : 25.03.2016; Accepted : 21.04 .2016

\section{MEMBERS OF RESEARCH FORUM: \\ Corresponding author : U.P. SHAHI, Department of Soil Science, Sardar Vallabhbhai Patel University of Agriculture and Technology, MEERUT (U.P.) INDIA Email: upshahi@gmail.com}

Co-authors :

MANOJ KUMAR, B.P. DHYANI, ASHOK KUMAR AND YOGESH KUMAR, Department of Soil Science, Sardar Vallabhbhai Patel University of Agriculture and Technology, MEERUT (U.P.) INDIA

\section{Summary}

A field experiment was conducted on wheat (Triticum aestivum L.) during Rabi season of 2005-06 at Crop Research Center of Sardar Vallabhbhai Patel University of Agriculture and Technology, Modipuram, Meerut. The experiment was aimed to evaluate the effect of different nitrogen scheduling and LCC based nitrogen scheduling in wheat. The experiment comprised of ten treatments was laid out in Randomized Block Design, with three replications. The major treatments were, control (where no nitrogen was applied ), $50 \% \mathrm{~N}$ in basal $+25 \% \mathrm{~N}$ at CRI +25 $\%$ at tillering stage, $25 \% \mathrm{~N}$ in basal $+25 \% \mathrm{~N}$ at CRI $+25 \% \mathrm{~N}$ at tillering $+25 \% \mathrm{~N}$ at jointing stage, $37.5 \% \mathrm{~N}$ in basal $+25 \%$ at CRI $+37.5 \% \mathrm{~N}$ at tillering stage, $50 \% \mathrm{~N}$ at CRI $+50 \% \mathrm{~N}$ at tillering stage, $50 \% \mathrm{~N}$ at CRI $+25 \% \mathrm{~N}$ at tillering $+25 \% \mathrm{~N}$ at jointing stage, $50 \mathrm{~N}$ in basal $+25 \%$ $\mathrm{N}$ at tillering $+25 \% \mathrm{~N}$ at jointing stage, $25 \% \mathrm{~N}$ in basal $+37.5 \% \mathrm{~N}$ at $\mathrm{CRI}+37.5 \% \mathrm{~N}$ at tillering, $25 \% \mathrm{~N}$ in basal $+50 \% \mathrm{~N}$ at CRI $+25 \% \mathrm{~N}$ at tillering stage, and nitrogen applied on LCC (Leaf colour chart) based. In different nitrogen scheduling treatments, LCC based nitrogen scheduling treatment was found most efficient than recommended and other nitrogen scheduling treatments in terms of increased wheat yield and nitrogen use efficiency. Application of $25 \% \mathrm{~N}$ in basal $+50 \% \mathrm{~N}$ at CRI $+25 \% \mathrm{~N}$ at tillering stage was also found superior than other treatments, increased these parameters, but it was inferior to the LCC based nitrogen scheduling treatment. $\mathrm{AE}_{\mathrm{N}}$ and $\mathrm{RE}_{\mathrm{N}}$ also improved due to $\mathrm{LCC}$ based nitrogen application. LCC based nitrogen scheduling practice also reduces the over application of nitrogen which can be susceptible to different losses including leaching, ammonium volatilization and runoff.

Key words : Nitrogen use efficiency, LCC, Nitrogen scheduling

How to cite this article : Shahi, U.P., Kumar, Manoj, Dhyani, B.P., Kumar, Ashok and Kumar, Yogesh (2016). Effect of nitrogen scheduling on nitrogen use efficiency and performance of wheat (Triticum aestivum L.) in light textured soil. Asian J. Soil Sci., 11 (1) : 78-81 : DOI : 10.15740/HAS/AJSS/11.1/ 78-81. 